Monika Marlicka-Robert

\title{
Okrutna bajka, czyli Otik Karela Jaromíra Erbena i Jana Švankmajera
}

Sylwetka Jana Švankmajera opisywana jest przez licznych krytyków filmowych, komentatorów i recenzentów wielobarwnie oraz przy użyciu szerokiego wachlarza takich określeń, jak surrealista, alchemik, magik, demiurg, szaman, filozof czy poeta. Nie bez znaczenia wydaje się też fakt, że sztuka Švankmajera to wielowątkowy kolaż wykorzystujący motywy i mity mniej lub bardziej popularnych i rozpoznawanych kulturowych tradycji.

Dzieła Švankmajera konsekwentnie potwierdzają jego świadomość bogactwa kulturowej i artystycznej tradycji. Sam reżyser twierdzi:

Twórczość, nie tylko filmowa, czerpie wyłącznie z impulsów, jakie trwale, natrętnie utkwiły w mej świadomości (i podświadomości), wpływając stamtąd, najczęściej w formie obsesji, na moje myśli i dokonania. Nie rozstrzygam, czy owe podniety docierają ze świata realnego, czy też ich nośnikiem są doznania artystyczne (Arcimboldo, Carroll, Poe, powieść gotycka itp.). Moje podejście do cudzych dzieł jest i tak zawsze opanowane przez interpretacyjne delirium, które ogarnia mnie na przekór selektywnej pamięci. Chcę się wyzbyć tych obsesji (mających zawsze charakter lękowy), filmuję je, czyli nazywam. Muszę jednakże wyznać, iż efekt wyzwolenia nie jest zjawiskiem trwałym ${ }^{1}$.

Nieprzypadkowo artysta przywołuje w swoich filmach dzieła takich twórców, jak Edgar Allan Poe, Lewis Carroll, D. A. F. de Sade, Horace Walpole czy Johann Wolfgang Goethe. André Breton, autor Manifestu surrealizmu, wymienia te właśnie nazwiska jako autorytety, których utwory stanowią źródła analogii ówczesnej myśli surrealistycznej w praktyce literackiej. Według Bretona, Poe jest surrealistą w przygodzie, a Sade - surrealistą

1 Jan Švankmajer, Z ankiet i wywiadów, tłum. Jan Gondowicz, „Kwartalnik Filmowy” 1997, nr 19-20, s. 237. 
w sadyzmie ${ }^{2}$. Również każdy z tych autorów na swój sposób jest naznaczony piętnem romantycznym, a jeśli ich dzieła nie są kwalifikowane do nurtu romantyzmu, to są jego dalszym echem lub przedromantyczną zapowiedzią. Sam Švankmajer wydaje się spadkobiercą i wyznawcą romantycznych ideałów, przyznając, że "surrealizm to rewolucyjny pogląd na życie i świat, to romantyzm XX wieku i dopóki nie ukształtuje się nowy romantyzm, surrealizm będzie przyciągać następne generacje. Surrealizm jest dla mnie przede wszystkim kolektywną przygodą, postawą antycywilizacyjną" ${ }^{\prime \prime}$. Irracjonalizm, przewaga intuicji nad rozsądkiem, bunt przeciw konwencjom i kanonom, tęsknota za spełnieniem oraz ciągła eksploracja własnego wnętrza i zakamarków ludzkiej duszy to cechy wielkich bohaterów romantycznych, które często kreują model zachowań postaci z filmów Švankmajera.

Po ukończeniu Wyższej Szkoły Rzemiosł Artystycznych Švankmajer kontynuował specjalizację w zakresie lalkarstwa w Akademii Sztuk Dramatycznych (DAMU), gdzie oprócz sztuki lalkarskiej zgłębiał tajniki reżyserii scenicznej oraz projektowania dekoracji. Jako przedstawienie dyplomowe przygotował adaptację sztuki Carla Gozzi pod tytułem Król Stag, w której wpadł na pomysł połączenia występu marionetek z grą aktorów na scenie. Następnie swój warsztat reżyserski rozwijał w praskich teatrach „Semafor" i „Laterna Magika”. Krótkometrażowy debiut filmowy powstał w 1964 r. i nosił tytuł Ostatnia sztuczka pana Schwarzwalda $i$ pana Edgara. W następnych latach Švankmajer zrealizował kolejne krótkie filmy: Gre w kamienie (1965), Et Cetera (1966), Historia naturae (1967) - filmową dedykację dla praskiego cesarza Rudolfa II, Mieszkanie (1968), Cichy tydzień w domu (1969) - w których do perfekcji opanował autorską metodę łączenia filmu animowanego, lalkowego i aktorskiego. Jego filmy coraz bardziej ewoluowały w kierunku surrealizmu, ruchu cieszącego się niesłabnącą popularnością w artystycznych kręgach Pragi.

Po siedmioletniej przerwie spowodowanej narzuconym przez cenzurę zakazem realizacji filmów reżyser otrzymał pozwolenie na powrót do pracy w filmie, po uprzednim zagwarantowaniu, że ograniczy się do adaptacji klasyki literackiej. Jeśli nawet nakaz ten stał się głównym impulsem, który spowodował, że artysta zaczął odwoływać się do tematów i motywów literackich, to już sam wybór dzieł literackich (1979-Zamczysko $w$ Otranto powstałe na motywach powieści grozy Horacego Walpole'a oraz

2 André Breton, Manifest surrealizmu, [w:] Surrealizm. Teoria i praktyka literacka. Antologia, wybór i przekł. Adam Ważyk, Wyd. Czytelnik, Warszawa 1976, s. 78.

3 Jan Švankmajer, Jestem surrealistą. Z Janem Švankmajerem rozmawia Bogusław Zmudziński, tłum. Józef Golian, „Kino” 2002, nr 4, s. 23. 
1980 - Zagłada domu Usherów i 1983 - Wahadło, studnia i nadzieja, będące adaptacjami mrocznych opowiadań Edgara Allana Poe) bez wątpienia świadczy o fakcie, że ograniczenie stało się okazją, a wręcz narzędziem realizacji dotychczasowych wizji artystycznych reżysera oraz wzbogacania jego poetyki filmowej. W 1982 r. Švankmajer zrealizował film, dzięki któremu zyskał światowy rozgłos i uznanie w kręgach filmowych oraz nagrodę Złotego Niedźwiedzia na festiwalu w Berlinie. Wymiary dialogu to metafora obrazująca zatracenie indywidualności jednostki i jej bełkotliwy sposób komunikowania się. W totalitarnym systemie Czechosłowacji film został sklasyfikowany przez Centralny Komitet Czechosłowackiej Partii Komunistycznej jako przykład obrazu szkodliwego, który w ogóle nie powinien być zrealizowany.

Pierwszy pełnometrażowy film Švankmajera, Coś z Alicji, powstał w 1987 r. i był wyrazem fascynacji reżysera twórczością Lewisa Carrolla, jednego z jego ulubionych pisarzy. Kolejne pełnometrażowe filmy to Faust (1994) - swobodna adaptacja motywów dzieł Johanna Wolfganga Goethego i Christophera Marlowe'a; Spiskowcy rozkoszy (1996) - zbiorowy portret jednostek ludzkich hołdujących wymyślnym erotycznym obsesjom; wywiedziony z ludowej bajki czeskiej Otik (2000) oraz Szaleni - obraz zrealizowany na motywach opowiadań Edgara Allana Poe i D. A. F. de Sade'a. Ostatni pełnometrażowy film reżysera to Przeżyć swoje życie (2010), za który Švankmajer otrzymał nagrodę Czeskiego Lwa w kategorii scenografia.

Otik Jana Švankmajera to autorska adaptacja bajki Ociosanek spisanej z ludowych podań przez Karela Jaromíra Erbena w połowie XIX w. Nie jest to jedyna bajka w zbiorach tego folklorysty i poety. Jako etnograf, historyk i pisarz Erben interesował się ludowym czeskim folklorem, czego wyrazem jest jego najsławniejsze dzieło, zaliczane do klasyki czeskiej literatury romantycznej - Kytice (ten zbiór ballad przeniósł na duży ekran F. A. Brabec). Pomysł realizacji filmowej wersji bajki podsunęła reżyserowi jego żona Eva, która, zafascynowana bajką oraz jej makabrycznym aspektem, wykonała ilustracje do książkowego wydania tego utworu, a także zamierzała zrealizować na jego motywach film animowany. Švankmajera w opowieści Erbena zaintrygował przede wszystkim jej uniwersalny wymiar, który niesie ze sobą prawdę charakterystyczną dla mitów: „Często sięgam do starych bajek, które są narracyjnymi mitami kosmogonicznymi. Mit o Ociosanku jest bardzo starym i kluczowym mitem cywilizacyjnym, który sięga tak samo daleko, jak mit Fausta, albo nawet dalej"'4.

4 Wywiad z Janem Švankmajerem, After revolution, the shit! Jan Svankmajer talks to The Context (tłum. autorki), www.google.pl/url?sa=t\&rct=j\&q=\%84after\%20revolution $\% 2 \mathrm{C} \% 20$ the $\% 20$ shit $\% 2 \mathrm{C} \% 20$ the $\% 20$ context\&source=web\&cd=1\&ved=0CBwQFjAA\&url=- 
To właśnie romantyczna fascynacja ludowością, widoczna w licznych nawiązaniach do legend, podań, starodawnych mitów i baśni, obok nawiązań i cytatów z klasyki literackiej, charakteryzuje twórczość autora Otika. Reżyser nie tylko korzysta z lokalnych czeskich podań, ale czerpie też z bogactwa kulturowej tradycji wraz z jej kosmogonicznymi mitami, które poddaje własnej interpretacji, a często odczytuje w nowy, oryginalny sposób. Według Mieletinskiego: „Mitologizm stanowi charakterystyczne zjawisko kultury XX wieku, zarówno jako metoda artystyczna, jak i wyrażany za pośrednictwem tej metody sposób przeżywania świata" ${ }^{\prime \prime}$. Mit jest zjawiskiem ogólnoludzkim, które przebija się ze zbiorowej podświadomości w postaci symboli i archetypów, będących wzorcami mitologicznych motywów. Autor ma świadomość obecności mitu w życiu codziennym, jego ewoluowania i wpływu na wzorce ludzkich działań, nadaje mu wymiar ponadczasowej prawdy i mocy determinującej los. Leszek Kołakowski twierdzi, że świadomość mityczna jest wszechobecna i istnieje „w każdym rozumieniu świata jako wyposażonego w wartości oraz w każdym rozumieniu historii jako sensownej [...]. Mityczna instancja odwoławcza, która wyprzedza wszelką historyczność i czyni ją relatywna, narzuca interpretowanie zdarzenia jako zgodnego albo niezgodnego z ludzkim powołaniem ${ }^{\prime \prime 6}$. Według Eliadego ${ }^{7}$ człowiek współczesny obcuje na co dzień ze „zdegradowanymi symbolami", swoim istnieniem powtarza schematy świętych, mitycznych opowieści, wciąż powraca do sytuacji, która miała miejsce in illo tempore w czasie świętym. Istniejące paralele między światem pierwotnych mitologii a współczesnym życiem wraz z jego formami ekspresji artystycznej pozwalają uznać, że Švankmajer świadomie sięga do mitycznego ",archiwum” i wykorzystuje kulturowy bagaż rytuałów, symboli i mitów, powołując do życia filmowy świat $\mathrm{w}$ formie mitycznych opowieści.

Relacje między mitem a bajką były badane przez wielu teoretyków. Niejednokrotnie stwierdzano, że bajka często czerpie z bogatego zasobu kultury mitów, wykorzystując i modyfikując legendarne motywy. Cechy mitologicznego myślenia, obrzędów i rytuałów znajdują swoje odbicie w wielu popularnych do dnia dzisiejszego bajkach. Jak twierdzi Mieletinski, „swoiście bajkową semantykę można interpretować tylko z per-

\footnotetext{
http\%3A\%2F\%2Fcgar.umwblogs.org\%2Ffiles\%2F2007\%2F10\%2Fafter-revolutionsvankmajer.doc\&ei=5An_TpGEM4P88QOyyPzIAQ\&usg=AFQjCNGvZdY4o-wb70Q87 Ft9xpU0i4Bs8A\&sig2=PvvyhX3wuxeQY4jUMzadTA\&cad=rja (dostęp: 11.07.2012).

5 Eleazar Mieletinski, Poetyka mitu, tłum. Józef Dancyngier, PIW, Warszawa 1981, s. 14.

6 Leszek Kołakowski, Obecność mitu, Wyd. Dolnośląskie, Wrocław 1994, s. 36-37.

7 Mircea Eliade, Sacrum, mit, historia. Wybór esejów, tłum. Anna Tatarkiewicz, PIW, Warszawa 1974.
} 
spektywy źródeł mitologicznych"․․ To, co odróżnia bajkę od mitu, to fakt, że zalicza się ona do literatury pięknej. Bajka traktowana jest jako świadoma fikcja, której uwaga skupia się nie na mitycznych bohaterach, a zwykłych ludziach, natomiast czas mityczny zastąpiony jest nieokreślonym czasem bajkowym.

Filmowy Otik zachowuje pewne cechy bajki narracyjnej. Przede wszystkim świadczy o tym fabuła z typową strukturą wydarzeń, prowadzącą, w uproszczeniu, do wysłowienia ogólnej nauki moralnej. W czeskiej kulturze obyczajów bajka ta opowiadana była przeważnie dzieciom, które cechowało nadmierne łakomstwo i miała za zadanie służyć jako ostrzeżenie przed skutkami obżarstwa. Jednak bardziej od oddania bajkowej atmosfery charakterystycznej dla tego gatunku Švankmajera interesowało wyeksponowanie i poszerzenie ogólnej wymowy utworu, którą jest jej wymiar dydaktyczny (notabene uznawany przez reżysera za grzech w sztuce filmowej: „Wybieraj przede wszystkim te tematy, do których masz stosunek ambiwalentny [...]. Jedynie w ten sposób unikniesz popełnienia największego grzechu: filmu z tezą" ${ }^{\prime \prime 9}$ ), a nawet całkowite wyjście poza ten obszar, w stronę swobodnej niejednoznacznej interpretacji.

Pisząc scenariusz, reżyser zastąpił czas bajkowy czasem współczesnym, czyli okresem końca lat 90 . XX w. Na miejsce akcji natomiast, zamiast bliżej nieokreślonej sielskiej wsi (tak jak w oryginale), wybrał wielkomiejską Pragę. Centrum głównych wydarzeń stanowi stara zaniedbana czynszowa kamienica z ciemną piwnicą oraz klaustrofobicznym podwórkiem zaadaptowanym na przydomowy ogródek. Drugim, równie ważnym dla rozwoju akcji miejscem jest podmiejska działka z letnią altanką, będącą własnością pary głównych bohaterów - małżeństwa Horáków.

Božena i Karel Horák to małżeństwo w średnim wieku, typowi przedstawiciele klasy średniej, których największym marzeniem jest posiadanie potomka. Scena, w której poznajemy bohaterów, rozgrywa się w przychodni, gdzie lekarz stawia parze nieodwołalną diagnozę - jest nią obustronna bezpłodność małżonków. Rozpacz bohaterów przejawia się w różnych formach - Horáková najpierw płacze, a potem popada w apatię i pakuje do walizki nagromadzone przez lata dziecięce kaftaniki. Horák jest bardziej opanowany, jednak stopniowo ulega podświadomym urojeniom. Za namową sąsiadów małżeństwo decyduje się na kupno letniskowego domku za miastem, gdzie Horák podczas porządkowania ogrodu

8 Eleazar Mieletinski, dz. cyt., s. 324.

9 Jan Švankmajer, Dziesięcioro przykazań, tłum. Krzysztof Wołosiuk, [w:] Czeska myśl filmowa, red. Andrzej Gwóźdź, słowo/obraz terytoria, Gdańsk 2005, s. 410. 
wykopuje korzeń, który kształtem przypomina mu niemowlę. Zabiera je do drewutni, gdzie nadaje mu ludzki kształt, formuje głowę i kończyny, po czym wręcza swojej żonie jako prezent na pocieszenie. Jej reakcja jest entuzjastyczna - kobieta natychmiast dostrzega w kawałku drewna żywe dziecko i zaczyna je poważnie traktować jako swojego potomka - przewija je, kąpie, smaruje kremami, ubiera w kaftanik. Taka reakcja zaskakuje Karela, jednak postanawia uczestniczyć w tej "grze" z nadzieją na poprawę samopoczucia żony (opór stawia dopiero wówczas, kiedy Božena chce zabrać korzeń do ich domu w mieście).

Nieożywiony korzeń stopniowo zaczyna ożywać - przewraca oczami, rusza patykowatymi placami i wydaje ludzkie dźwięki. Aby nie rozstawać się już więcej z „dzieckiem”, Horáková wprowadza w życie swój plan pozoruje swoją ciążę wypychając sobie brzuch przygotowanymi na każdy miesiąc odpowiedniej wielkości poduszkami, informując $w$ ten sposób wszystkich sąsiadów o przyszłym potomku. (- Po co ta szopka? - Za dziewięć miesięcy będziemy mieli nasze dziecko na stałe... Nie tylko w soboty i w niedziele, i nikt nie będzie mógt powiedzieć, że je ukradliśmy).

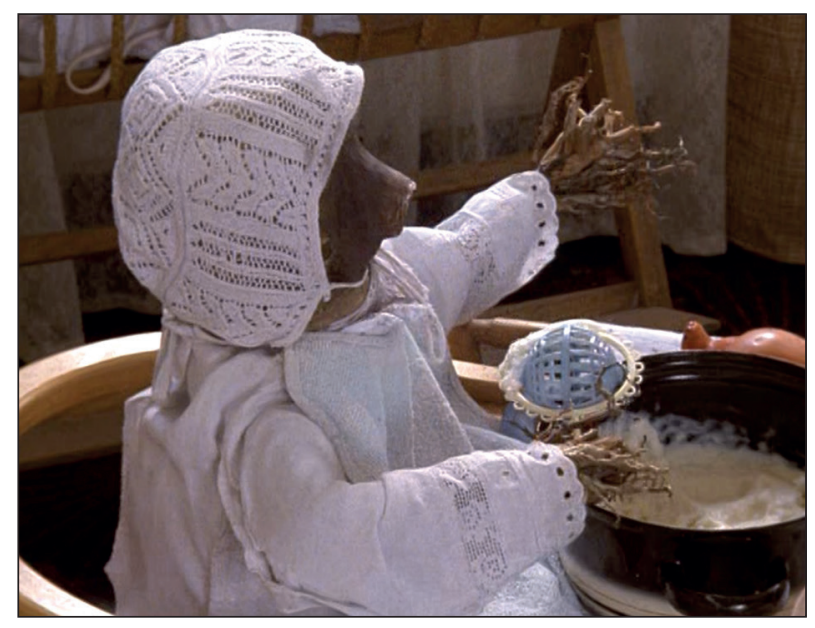

Fot. 10. Otik (2000, reż. Jan Švankmajer)

Otik podczas śniadania

Po dziewięciu miesiącach małżonkowie przywożą „nowo narodzonego" Otika do swojego mieszkania, skrzętnie ukrywając jego wygląd. Wszystkie przeszkody związane z utrzymaniem w tajemnicy wyglądu dziecka okazują się jednak niczym w porównaniu z nowym problemem dramatycznie rosnącym łakomstwem syna, któremu stopniowo przestają 
wystarczać butelki z mlekiem. Pierwszą ofiarą żarłoczności Otika staje się kot Mikeš. Następnie znika listonosz, a w dalszej kolejności pracownica opieki społecznej, która przychodzi na kontrolę po tym, jak zaniepokojona sąsiadka zgłasza na policji, że Horáková wozi w wózku lalkę, a nie niemowlę. Poczynania rodziców Otika są przez cały czas obserwowane przez małą rezolutną dziewczynkę, jedyne dziecko w kamienicy - Alžbětkę. Ona pierwsza ich demaskuje, bacznie obserwując rozwój wypadków. Kiedy po kolejnym dramatycznym wydarzeniu Horákowie, nie bez zażartej kłótni, dochodzą do wniosku, że bezpieczniej będzie zamknąć (olbrzymich już rozmiarów) Otika w piwnicy, Alžbětka jest jedyną osobą, która go odwie$\mathrm{dza}$, a potem się nim zajmuje, bawi i karmi - najpierw resztkami obiadu, a potem wybranymi $\mathrm{w}$ drodze losowania mieszkańcami kamienicy. Giną po kolei - starszy pan Zlabek, Horák (który zjawia się w piwnicy z ostatecznym zamiarem pocięcia syna piłą spalinową) oraz Horáková. Ostatnim posiłkiem Otika są główki kapusty z przydomowego ogródka w odwecie za ten czyn właścicielka rabatek (Babcia) uzbrojona w motykę schodzi do piwnicy z zamiarem zabicia potwora. Z bajki o Ociosanku, której książkową wersję czyta w tym czasie Alžbětka, dowiadujemy się, że potwór ginie, a z jego brzucha wyskakują po kolei wszystkie jego ofiary.

Podobnie jak w wielu bajkach, sytuacją wyjściową utworu jest w Ociosanku "brak", który stanowi według Proppa jedną z funkcji bajkowych struktur („Przez funkcję rozumiemy postępowanie osoby działającej określane z punktu widzenia jego znaczenia dla toku akcji $\left.{ }^{\prime \prime 10}\right)$. Brak obejmuje parę głównych bohaterów, którzy należą do grupy „osób działających” (według klasyfikacji Proppa). Sytuacja ta ma kluczowe znaczenie dla toku wydarzeń, staje się bowiem źródłem motywacji działań bohaterów. Uczucie pustki odczuwane przez bohaterów jest zasygnalizowane już od pierwszych scen filmu, kiedy Horák dostrzega wokół siebie same kobiety w ciąży, a potem ma urojenia - w środku rozkrawanego arbuza widzi płaczącego noworodka, zaś wyjrzawszy przez okno ze zdumieniem odkrywa, że uliczny handlarz sprzedaje niemowlęta na wagę, wyławiając je $\mathrm{z}$ basenu niczym świąteczne karpie, zaś on sam stoi po nie w kolejce. Obsesyjne pragnienie posiadania potomka osiąga kulminację $\mathrm{w}$ momencie, gdy mężczyzna w wykopanym korzeniu drzewa dostrzega podobieństwo do ludzkiego dziecka. Scena ta stanowi punkt wyjścia do dalszych wydarzeń - Horák decyduje się zabrać korzeń do domu i wręczyć go swojej

10 Władimir Propp, Morfologia bajki, tłum. Wiesława Wojtyga-Zagórska, Książka i Wiedza, Warszawa 1976, s. 56. 
małżonce. Stosując systematykę Proppa, dalszy rozwój wypadków można zinterpretować jako następujące działania: likwidacja wcześniej zaistniałego braku, roszczenia fałszywego bohatera, szkodzenie, rozpoczynające się przeciwdziałanie albo ukaranie oraz ocalenie ${ }^{11}$. Wymienione funkcje mogą być rozpoznane jedynie $\mathrm{w}$ wymiarze interpretacji przewodniego wątku zgodnego z bajkowym oryginałem.

Jak wyjaśnia reżyser ${ }^{12}$, tytuł utworu w języku czeskim (Otesánek) odsyła do słowa „ociosywać” (otesávat), które po dodaniu końcówki -ánek tworzy zdrobnienie rzeczownika używane najczęściej w odniesieniu do dzieci. W ten sposób powstało popularne w Czechach metaforyczne określenie osoby uwielbiającej dużo jeść, chorobliwie wręcz żarłocznej, konsumującej nie tylko produkty nadające się do spożycia. Pomimo faktu, że filmowi rodzice nadają głównemu bohaterowi imię Otik (czyn ten może być interpretowany jako akt oswojenia nieznanego, wprowadzenia go do społeczności), pan Horák („,ojciec” Otika) konsekwentnie przejęzycza się, odruchowo używając określenia „ociosanek”. Zauważywszy niewłaściwość tego przydomku, nie kończy wyrazu, wymawiając komiczne „ocios”.

Reżyser dość wiernie odtworzył główny wątek bajkowy, jakim jest historia młodego małżeństwa, które pragnie mieć dziecko. Ich marzenie zamienia się w obsesję, która sprawia, że wykopany z ziemi korzeń drzewa zaczynają traktować jako własnego potomka, troskliwie się nim opiekując. Pod wpływem tego uczucia kawałek drewna ożywa, a jego rosnący niepohamowany apetyt staje się przyczyną coraz większych tragedii. Jednak ten przewodni motyw został nieco zmodyfikowany poprzez dodanie kilku nowych wątków pobocznych, co nadało historii bardziej współczesny i społeczny wymiar. W oryginalnym utworze w ogóle nie występuje postać Alžbětki, córki Štádlerów - sąsiadów państwa Horáków, która zaprzyjaźnia się z Otikiem. W filmie wątek tej rodziny odgrywa istotną rolę w tworzeniu dramaturgii wydarzeń - wiele obserwacji czynionych jest z punktu widzenia sąsiadów państwa Horák, a zwłaszcza małej ciekawskiej Alžbětki.

Równolegle do współczesnej historii widz ma możliwość śledzenia losów bajkowego Ociosanka utrwalonych przez Erbena - jego perypetie ukazane są $\mathrm{w}$ formie klasycznego filmu animowanego, którego sekwencje pojawiają się w scenach, kiedy Alžbětka czyta książkową wersję bajki. Mamy tu do czynienia ze strukturą "filmu wewnątrz filmu”. Odczy tanie kolejnych

11 Tamże.

12 Wywiad z Janem Švankmajerem, Bringing Up Baby, Peter Hames, „Kinoeye” 2002, nr 1 (tłum. autorki), www.kinoeye.org/02/01/hames01.php (dostęp: 11.07.2012). 
fragmentów przez dziewczynkę zawsze wyprzedza o krok „rzeczywiste” wydarzenia. Jako że jest ona jedyną osoba, która jest świadoma dalszego rozwoju wy padków, w pewien sposób spełnia funkcję wszechwiedzącego narratora (Zaczęło się! A to dopiero początek - mówi). W rzeczywistości jest ona idealną osobą do przejęcia stymulującej dramaturgię funkcji narracyjnej, gdyż jako dziecko, z którego zdaniem nikt się z zasady nie liczy, ma ona - przy jednoczesnym pozostawaniu w ukryciu - możliwość dogłębnej i niczym nieskrępowanej obserwacji życia rodzinnego Horáków oraz dysponuje swobodą działania. Jej komentarze są przez dorosłych traktowane z pobłażliwością jako dziecinne fantazje (Mamo, nie styszałaś, czy ktoś w okolicy nie zginat?). Dziecięca wyobraźnia pozwala jej wierzyć w imaginacyjny świat bajek, co umożliwia - jak zauważa Švankmajer ${ }^{13}$ - jej komunikację ze światem mitu i archetypu. Jako osoba obserwująca rozwój akcji z ukrycia, bohaterka pierwsza dostrzega niecodzienne zachowanie Horáków i odkrywa ich tajemnicę. Jej rola nie ogranicza się jednak do biernej obserwacji i komentowania sytuacji - dziewczynka wkracza w rejony aktywnej ingerencji, chcąc za wszelką cenę wpłynąć na bieg wydarzeń i zapobiec ich nieuchronnemu tragicznemu końcowi.

Inną charakterystyczną cechą struktury bajkowej jest ograniczona liczba bohaterów reprezentujących określone role społeczne. Do postaci, które Švankmajer dosłownie przenosi z bajki, należą Ociosanek, jego rodzice i babcia (właścicielka ogródka z kapustą). Jednak ich funkcje, postrzegane z punktu widzenia analizy struktury bajki, są niejednoznaczne i niedokładnie określone. Božena Horáková i Karel Horák - para głównych bohaterów - są w pewnym stopniu postaciami antonimicznymi. Narastający konflikt ich charakterów znacznie wzbogaca dramaturgię, pozwalając na zaistnienie sytuacji tragicznych, które niejednokrotnie prowadzą do groteski i czarnego humoru, np. w scenie, kiedy Horák chce porąbać Ociosanka siekierą: - Najpierw mnie zabij, a potem nasze dziecko! Ty morderco! Chcesz zabić własne dziecko! [...] - Przecież wiesz, że go kocham.

Horáková uosabia archetyp kobiety-matki, dla której największą wartością w życiu jest możliwość posiadania i wychowywania potomstwa. Fakt, że jest to $\mathrm{w}$ rzeczywistości niemożliwe, jeszcze bardziej podkreśla i uwypukla jej obsesyjne zachowania (choćby ciągłe składanie dziecinnych kaftaników). Kiedy otrzymuje od męża wyciosany w kształcie niemowlaka korzeń, natychmiast zauważa w nim żywą istotę, ludzkie bezbronne dziecko. Bez wahania przyjmuje je jako swoje własne, wykonując wszelkie

13 Jan Švankmajer, František Dryje, Síla imaginace: režisér o své filmové torbé, Dauphin, Praha 2001, s. 104 (tłum. autorki). 
rytualne czynności matki - kąpanie, przewijanie, ubieranie czy karmienie piersią. Stopniowe ożywanie korzenia może być traktowane nie tylko jako filmowy zabieg animacji przedmiotu, lecz także wizualizacja urojeń kobiety. Jej instynkt macierzyński jest tak głęboki, że tłamsi racjonalność zachowań - Božena nie przyjmuje do wiadomości zdroworozsądkowych tłumaczeń męża, zaskoczonego jej emocjonalnym zaangażowaniem. Konsekwentny upór Boženy, połączony z jej naiwnym optymizmem oraz bezkrytyczną akceptacją coraz bardziej niebezpiecznych zachowań Otika, niemalże graniczy z lekkomyślnością, a nawet szaleństwem. „Matka kocha wszystkie swoje dzieci jednakowo i bez zastrzeżeń, ponieważ miłość swą wyprowadza z faktu, iż są one jej dziećmi, niezależnie od zasług i osiągnięćc ${ }^{\prime 14}$ - pisze Erich Fromm. Pod tym względem bohaterka należy do świata matriarchalnego, gdzie istnieje tylko jeden święty węzeł - jest to więź łącząca matkę z dzieckiem. Tak odmienne postawy małżonków mogą być interpretowane jako odwieczny konflikt między emocjonalną kulturą matriarchalną a praktycznym światopoglądem patriarchatu. Jak twierdzi Fromm:

\begin{abstract}
kultura matriarchalna charakteryzuje się akcentowaniem więzi krwi, przywiązania do gleby oraz biernej akceptacji wszystkich zjawisk przyrody. Społeczeństwo patriarchalne, na odwrót, cechuje poszanowanie dla ustanowionego przez człowieka prawa, przewaga myśli racjonalnej oraz podejmowane przez ludzkość starania, aby przeobrazić zjawiska przyrody ${ }^{15}$.
\end{abstract}

Charakterystyka ta doskonale pasuje do państwa Horáków. Stanowisko mężczyzny okazuje się jednak dosyć chwiejne i niekonsekwentne (To co ja mam robić? - zastanawia się Horák), bowiem z czasem zaczyna on ulegać żonie, staje się coraz bardziej pasywny w swoim buncie i chęci zlikwidowania odmieńca, jego próby sprzeciwu są coraz rzadsze. Niczym biblijny Adam, bohater ulega namowom żony. W ostatnim akcie odzyskuje jednak swój głos i po kolejnych makabrycznych wydarzeniach przejmuje inicjatywę.

Nieprzypadkowo także w tej ludowej czeskiej bajce materiałem, z jakiego "stworzono” potomka jest drzewo. Sam reżyser mówi: „Ociosanek musi być bardzo starą bajką, ponieważ wykorzystuje motyw drzewa - drzewo ze swoimi korzeniami i gałęziami jest symbolem klasycznym:

14 Erich Fromm, Zapomniany język. Wstęp do rozumienia snów, baśni i mitów, tłum. Józef Marzęcki, PIW, Warszawa 1994, s. 179.

15 Tamże. 
korzenie zapuszczone są $\mathrm{w}$ mrocznych podziemiach (może nawet $\mathrm{w}$ piekle), a gałęzie pną się do niebios ${ }^{\prime 16}$. Istotnie, w kulturze mitów i podań drzewo, a tym samym i drewno, występuje w szerokim kontekście symbolicznym. W biblijnym Raju istniało Drzewo wiadomości dobrego i złego, którego owoce Bóg zakazał spożywać Adamowi. Złamanie zakazu przez Adama i Ewę oznaczało utratę niewinności i stało się lekcją nauki rozróżniania dobra od zła. W mitologii wielu ludów drzewo było m.in. traktowane jako symbol życia i życiodajnych sił, przypisywano mu znaczenie magiczne i dobroczynne właściwości zapładniające. Zwłaszcza w okresie średniowiecza pozycja i znaczenie drewna w wierzeniach, praktykach i społecznej wrażliwości były szczególnie znaczące. Dla ludzi średniowiecza drzewo przede wszystkim było materią żywą, która często stanowiła przedmiot antropomorficznej charakterystyki (wiele łacińskich metafor z tamtego okresu przypisuje korze właściwości skóry człowieka, a samemu drzewu - silną indywidualność oraz ludzką cechę posiadania humorów i nastrojów). W XIII w. Albert Wielki napisał o drewnie: „Można zaobserwować jego sęki, nieprawidłowości wzrostu, jego rysy i otwory: podobnie jak istota ludzka może cierpieć, gnić lub zostać zranione; jak w człowieku mogą się w nim zalęgnąć robaki"17. Ociosanek jako bajka ludowa (tzw. bajka magiczna) potwierdza zatem symboliczne i magiczne znaczenie drzewa w świadomości historycznych ludów.

Podświadome skojarzenie kawałka drewna z żywą istotą ma miejsce również w filmie. Widok wykopanego ukorzenionego pnia, który do złudzenia przypomina kształty dziecięce, podświadomie wzbudza u Horáka emocje i uczucia opiekuńcze. Kierowany wewnętrznym instynktem, decyduje się on nadać drewnu jeszcze bardziej ludzki kształt - wystruguje kończyny z palcami, tułów oraz głowę. Gaston Bachelard, przywołując scenę z Eine Kindheit Hansa Carossy (gdzie bohater we śnie otrzymuje trzy kule z bladoróżowej masy po to, by ulepić z nich dziecko), pisze: „Tworzyć - wielkie słowo - to tworzyć dziecko [...]. Podświadome modelowanie nie interesuje się rzeczami, lecz istotami ożywionymi. Dziecko pozostawione samo sobie lepi kurę lub królika. Tworzy życie"18. Taki instynktowny odruch kształtowania żywej istoty, wzmocniony silnym pragnieniem ujrzenia potomka, doprowadzają do „narodzin” Otika. W procesie kreacji uczestniczy również Horáková, o ile bowiem mężczyzna

16 Wywiad z Janem Švankmajerem, After revolution, the shit!...

17 Cyt. za: Michel Pastoureau, Średniowieczna gra symboli, tłum. Hanna Igalson-Tygielska, Oficyna Naukowa, Warszawa 2006, s. 92.

18 Gaston Bachelard, Wyobraźnia poetycka. Wybór pism, tłum. Henryk Chudak, Anna Tatarkiewicz, PIW, Warszawa 1975, s. 241. 
odpowiedzialny jest tutaj za manualną czynność wystrugania korzenia i nadania mu fizycznego kształtu, o tyle kobieta swoim matczynym uczuciem doprowadza do ożywienia drewnianej istoty. W scenie karmienia dziecka piersią jest upozowana na Marię karmiącą - jedno z bardziej popularnych przedstawień ikonograficznych Marii z Nazaretu, matki Jezusa Chrystusa. W szerszej interpretacji odwołującej się do wierzeń innych kultur, także pogańskich, bohaterka może być również uznana za Boginię Matkę (zwaną również Matką Ziemią czy Królową Niebios) - bohaterkę mitu o stworzeniu świata i dawaniu życia, który mówi o kreacji okupionej poświęceniem. Jak twierdzi Eliade, „Mityczny schemat zawsze jest ten sam: stworzyć można coś jedynie przez poświęcenie się, przez ofiarę ${ }^{\prime 19}$. Poświęcenie Horáków osiąga niemal heroiczne rozmiary i jest okupione cierpieniem (wysiłki, aby zaspokoić nieposkromiony głód „syna”, izolacja od społeczeństwa, kłamstwo, przestępstwo). Z powodu coraz bardziej okrutnego i agresywnego zachowania Otika popadają oni nie tylko w konflikt z własnym sumieniem, lecz także z prawem, zacierając wszelkie ślady jego ludożerczych aktów.

Intencja powołania do życia nowej istoty to wreszcie reminiscencja mitycznego aktu stwórczego, korespondującego z boską kreacją. Wyciosując postać z drewna, bohater doświadcza procesu sakralnego. Podobnie jak w legendzie o Golemie, przywłaszcza on sobie boskie prawo kreacji żywego organizmu i tym samym sprowadza na siebie karę niebios - zarówno gliniany Golem, jak i drewniany Otik są tworami powstałymi za pomocą ludzkich dłoni; rozwijając się, stają się coraz bardziej autonomiczni i przejmują kontrolę nad stwórca, doprowadzając do jego stopniowej degradacji. Czyny Ociosanka są swoistym głosem natury - ożywając, pieniek stopniowo przeistacza się w krwiożerczą bestię, staje się agresywnym ludojadem, którego nie są w stanie pohamować żadne ludzkie moce. Peter Hames we wstępie do wywiadu z reżyserem pisze: „tradycyjne ludowe motywy pojawiającego się ludojada i kanibalizmu są tu namacalne, ale to zazwyczaj potwór albo przybrany rodzic zagraża dziecku, tutaj to dziecko pożera swoich własnych rodziców'20.

Połknięcie przez potwora to motyw obecny w wielu mitach i przedstawiany w niezliczonych wariantach. Biblijna opowieść o Jonaszu połkniętym przez wieloryba jest jednym $\mathrm{w}$ wielu tego typu przestawień, którego symbolika rozpatrywana jest w kategoriach obrzędu inicjacyjnego - misterium symbolicznej śmierci i zmartwychwstania. Znalezienie

19 Mircea Eliade, dz. cyt., s. 194.

20 Wywiad z Janem Švankmajerem, Bringing Up Baby... 
się we wnętrznościach potwora może oznaczać również powrót do stanu embrionalnego charakterystycznego dla istoty jeszcze nienarodzonej. Według Mieletinskiego mamy tu do czynienia z podwójnym symbolizmem: symbolem śmierci jako kresu egzystencji doczesnej i końca czasu oraz symbolem powrotu do krótkotrwałego stanu zarodkowego poprzedzającego wszelką formę $e^{21}$.

Interpretacja motywu pożerania w filmowym Otiku może także zaistnieć w różnych kategoriach. Drewniany potomek, jako element natury, kieruje się pierwotnym instynktem zaspokojenia głodu, nie powstrzymuje się nawet przed połknięciem rodziców. W innym wymiarze można ten czyn rozumieć jako akt zemsty natury za narzucenie obcych jej norm społecznego porządku, rodzaj śmiertelnego odwetu prowadzącego do wyzwolenia. W tym znaczeniu natura, pochłaniając to, co jej się sprzeciwiło, unicestwia swojego wroga. Švankmajer sugeruje dodatkowy wymiar postrzegania krwiożerczego Otika, bowiem dostrzega w nim odbicie współczesnego świata: Otik , ,[...] symbolizuje potrzeby naszej cywilizacji, jej dążenie do pożerania wszelkiego rodzaju rzeczy: grup etnicznych, kultur'222. Kanibalizm bohatera stanowi zatem również metaforę relacji międzyludzkich, zarówno w obrębie jednostki, jak i szerszych grup społecznych.

Bajka o Ociosanku, jak przyznaje Švankmajer, jest „tematyczną wersją mitu Fausta: buntem przeciwko naturze i tragicznym wymiarem tego buntu"23. Państwo Horákowie, decydując się na „wychowanie” kawałka drewna, dążą do urzeczywistnienia swoich marzeń o posiadaniu potomka. W egoistycznym odruchu gwałcą oni boskie prawa - zawierają swego rodzaju przymierze z diabelskimi siłami, aby to, co nieosiągalne, stało się realne. Dla państwa Horáków, tak jak dla Fausta, nie ma już wyjścia z sytuacji, fatalizm zakończenia jest przesądzony. Jedyna różnica polega na rodzaju kary. Faust (według wersji Marlowe’a) w ostatniej chwili sprzeciwia się Lucyferowi, z którym wcześniej podpisał pakt, i tym samym sprowadza na siebie karę Szatana. Natomiast wszelkie próby Horáków, dążących do tego, aby ujarzmić rozpętane zło (np. uwięzienie Otika w piwnicznej skrzyni) są spóźnione i jedynie pogarszają sytuację. „Ludzie, którzy dostaną się pod wpływ mitu, który powołają do życia za pomocą niewinnego czynu - zauważa Švankmajer - nagle nie mogą się z niego wyzwolić i są nim manipulowani, wiedzeni imaginacyjną

21 Eleazar Mieletinski, dz. cyt., s. 235.

22 Wywiad z Janem Švankmajerem, A Quick Chat with Jan Svankmajer and Eva Svankmajerová, Jason Wood (tłum. autorki), www.kamera.co.uk/interviews/svankmayer_ svankmajerova.html (dostęp: 11.07.2012).

23 Wywiad z Janem Švankmajerem, Bringing Up Baby... 
logiką aż do gwałtownego końca"24. Otik jest ucieleśnieniem takiego mitu, zaczyna żyć własnym życiem, wymyka się spod kontroli i w rezultacie zostaje wyrzucony na margines społeczeństwa, które nie potrafi z nim nawiązać kontaktu. Horákowie, nie będąc w stanie rozwiązać problemu, próbują go ukryć - ich działania wydają się podyktowane egoistycznym impulsem, chęcią zamaskowania wcześniejszej żądzy. Kara, jaka ich spotyka, jest więc pierwotną karą boską - potępieniem Adama i Ewy, którzy zrywając zakazany owoc, łamią boskie prawo, za co zostają wygnani z Raju.

W oryginalnej wersji Ociosanka, tak jak w innych bajkach, których bohaterowie zostają pożarci przez potwora (np. bajka o Czerwonym Kapturku), historia ma szczęśliwe zakończenie - babcia, zabijając potwora, przebija motyką jego brzuch, z wnętrza którego wychodzą ocaleni bohaterowie. Švankmajer ogranicza się jedynie do sugestii, że żywot Otika dobiegł już końca - ostatnia scena przedstawia babcię schodzącą z motyką do piwnicy oraz płaczącą Alžbétkę, która ostatnimi siłami próbuje zapobiec tragedii i ocalić życie przyjaciela. Kiedy los bohatera jest już przesądzony, słyszymy ostanie słowa bajki: I wyskoczył z brzucha pies Vořišek, za nim owczarz, a za owczarzem owce, a później wybiegło stado prosiat. $\mathrm{O}$ ile w bajce zakończenie można interpretować jako szczęśliwe, o tyle w filmie nie jest to tak jednoznaczne - przywrócenie pożartym ofiarom życia niewątpliwe jest czynem pozytywnym, lecz zagłada Otika wywołuje już bardziej ambiwalentne uczucia. Jak twierdzi Hames ${ }^{25}$, bohater jest w pewnym sensie lalką, lecz w kilku scenach można go postrzegać jako żywą ludzką istotę, która potrafi czuć i odwzajemniać uczucia innych.

Pomimo swojego okrutnego oblicza i przerażającego wyglądu (zbliżenia twarzy potwora ukazują jego wampiryczne uzębienie, czerwone dziąsła i olbrzymi język), Otik łka jak niemowlę i wykazuje właściwości charakterystyczne dla dziecka - potrzebuje opieki i towarzystwa, interesuje się zabawkami, szybko się uczy (scena, kiedy Ociosanek przed jedzeniem myje sobie „ręce”). Postać wzbudza przerażenie i wstręt, a jednocześnie wywołuje współczucie. Uczucie empatii stopniowo narasta, bowiem Otik coraz bardziej przypomina ofiarę, która, wyrwana ze swojego naturalnego środowiska i uwięziona, jest skazana na cierpienie, stając się tym samym „materializacją pragnień i buntu przeciwko naturze ${ }^{\prime 26}$. Ociosanek

\footnotetext{
24 Jan Švankmajer, František Dryje, dz. cyt., s. 202.

25 Peter Hames, Czech and Slovak Cinema, Theme and Tradition, Edinburgh University Press Edinburgh 2009, s. 183 (tłum. autorki).

26 Wywiad z Janem Švankmajerem, Bringing Up Baby...
} 
jest jak rozpętany żywioł, którego krzyk jest głosem sprzeciwu wobec nieposzanowania istniejącego od wieków porządku świata, a także uzurpatorskiej postawy człowieka wobec natury. Zatem morał filmowej bajki jest nadzwyczaj wielowymiarowy i aktualny - ukazuje bowiem władczy stosunek człowieka i jego kultury do pierwotnych praw natury. Švankmajer, postulując swój pogląd, wydaje się ostrzegać przed konsekwencjami samozniszczenia (jedną z nich, na przykład, może być problem bezpłodności), do którego zmierza współczesny człowiek. Daleki od ścisłego definiowania metafory i przesłania bajki, wydaje się wskazywać, iż Ociosanek jest w każdym z nas. 